Updates

\begin{tabular}{|c|c|}
\hline \multicolumn{2}{|c|}{ Updates to statistics on www.statistics.gov.uk } \\
\hline 14-Jan & 26-Jan \\
\hline Producer prices & Never worked households \\
\hline Factory gate inflation rises $4.2 \%$ & 352,000 households never worked \\
\hline www.statistics.gov.uk/cci/nugget.asp?id=248 & www.statistics.gov.uk/cci/nugget.asp?id=1163 \\
\hline 18-Jan & Graduates in the labour market \\
\hline Inflation & Unemployed graduates double \\
\hline CPI inflation $3.7 \%, R P I$ inflation $4.8 \%$ & www.statistics.gov.uk/cci/nugget.asp?id=1162 \\
\hline www.statistics.gov.uk/cci/nugget.asp?id=19 & \\
\hline & 31-Jan \\
\hline 19-Jan & Local unemployment \\
\hline Average weekly earnings & Rates vary between $2.9 \%$ and $14.1 \%$ \\
\hline Regular pay growth unchanged & www.statistics.gov.uk/cci/nugget.asp?id=1606 \\
\hline www.statistics.gov.uk/cci/nugget.asp?id=10 & \\
\hline & Local employment \\
\hline Employment & Rates vary between $55.5 \%$ and $86.0 \%$ \\
\hline Rate falls to $70.4 \%$ & www.statistics.gov.uk/cci/nugget.asp?id=252 \\
\hline www.statistics.gov.uk/cci/nugget.asp?id=12 & \\
\hline & 09-Feb \\
\hline 21-Jan & UK Trade \\
\hline Retail sales & Deficit widened to $£ 4.8$ billion in December \\
\hline Snow dampens retail sales growth & www.statistics.gov.uk/cci/nugget.asp?id=199 \\
\hline www.statistics.gov.uk/cci/nugget.asp?id=256 & \\
\hline & $10-\mathrm{Feb}$ \\
\hline 25-Jan & Index of production \\
\hline GDP growth & Production: $3.6 \%$ annual rise \\
\hline UK output decreases by $0.5 \%$ & www.statistics.gov.uk/cci/nugget.asp?id=198 \\
\hline www.statistics.gov.uk/cci/nugget.asp?id=192 & \\
\hline & Travel and tourism \\
\hline Public sector finances & Visits abroad fall further \\
\hline Monthly: record for net borrowing & www.statistics.gov.uk/cci/nugget.asp?id=352 \\
\hline www.statistics.gov.uk/cci/nugget.asp?id=206 & \\
\hline Index of services & \\
\hline $1.5 \%$ annual rise into November & \\
\hline www.statistics.gov.uk/cci/nugget.asp?id=558 & \\
\hline
\end{tabular}




\section{Forthcoming releases}

Future statistical releases on www.statistics.gov.uk

$11-F e b$

Output and employment in the construction industry - December 2010

Producer price index - December 2010

15-Feb

Consumer price indices - January 2011

International comparisons of productivity - Revised 2009

Financial statistics - February 2011

$16-F e b$

Labour market statistics - February 2011

Average weekly earnings - December 2010

18-Feb

Retail sales - December 2010

Turnover and orders in production and services industries - December 2010

22-Feb

Health Statistics Quarterly - Spring 2011

Public sector finance - January 2011

23-Feb

Services producer price indices - Q4 2010

Sickness absence in the labour market - February 2011

24-Feb

Migration statistics quarterly report - February 2011

Social Trends - Spotlight on subjective well-being

25-Feb

UK output, income and expenditure - Q4 2010

Index of services - December 2010

Business investment provisional results - Q4 2010
01-Mar

Mergers and acquisitions involving UK companies - Q4 2010

02-Mar

Older workers in the labour market - March 2011

03-Mar

Regional Trends - Portrait of the North West

04-Mar

New orders in the construction industry - Q4 2010

09-Mar

UK Trade - January 2011

10-Mar

Overseas travel and tourism - January 2011

Index of production - January 2011

11-Mar

Producer price index - February 2011

Output in the construction industry - January 2011

15-Mar

Financial Statistics - March 2011

CPI and RPI: the 2011 basket of goods and services

Annual survey of hours and earnings pension tables $\mathbf{- 2 0 1 0}$ 